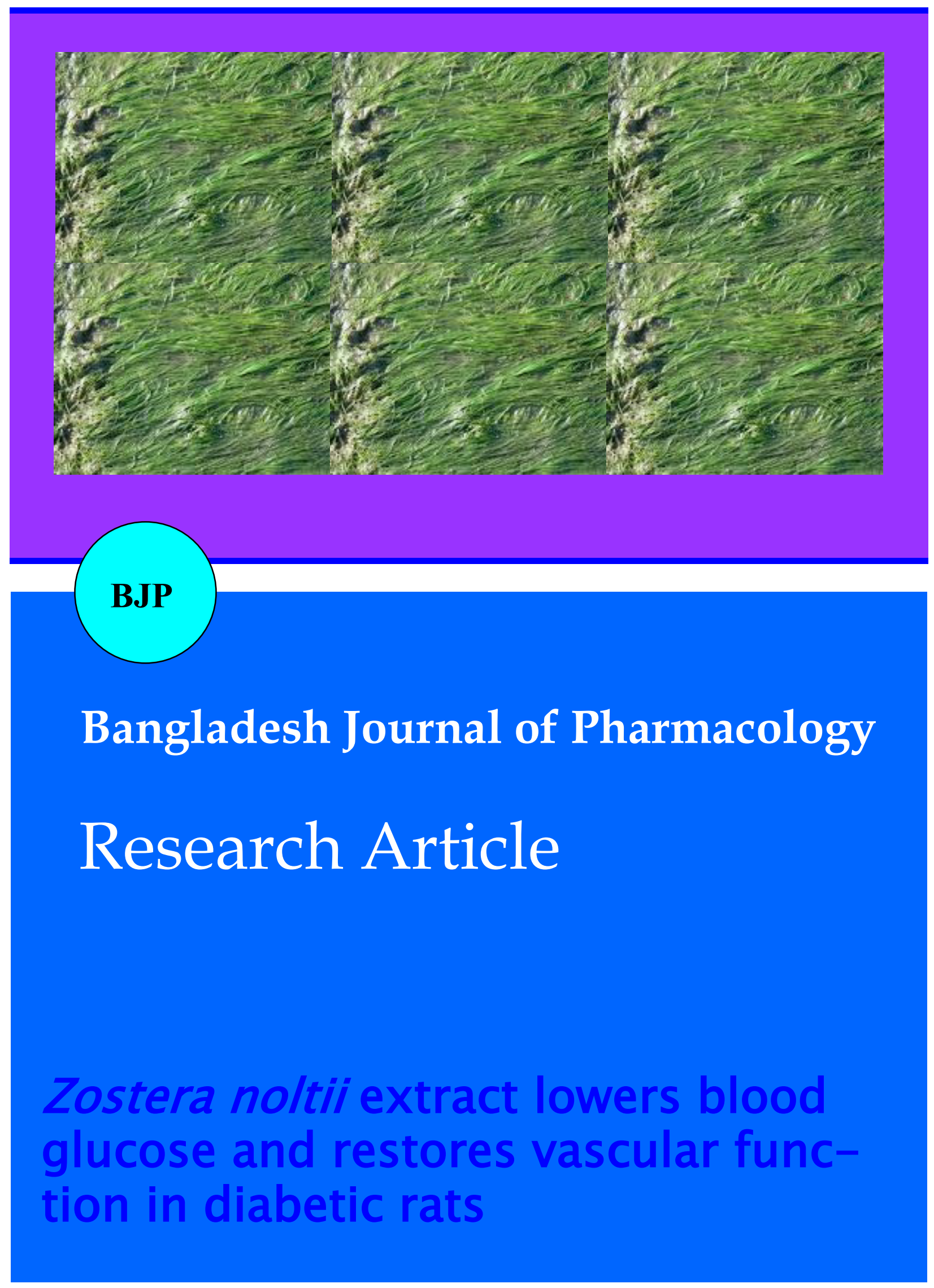




\section{Zostera noltii extract lowers blood glucose and restores vascular function in diabetic rats}

\section{Mehmet Zeki Haznedaroglu' ${ }^{1}$ and Goksel Gokce ${ }^{2}$}

${ }^{1}$ Ege University, Faculty of Pharmacy, Department of Pharmaceutical Botany 35100, Bornova, Izmir, Turkey; ${ }^{2}$ Ege University, Faculty of Pharmacy, Department of Pharmacology 35100, Bornova, Izmir, Turkey.

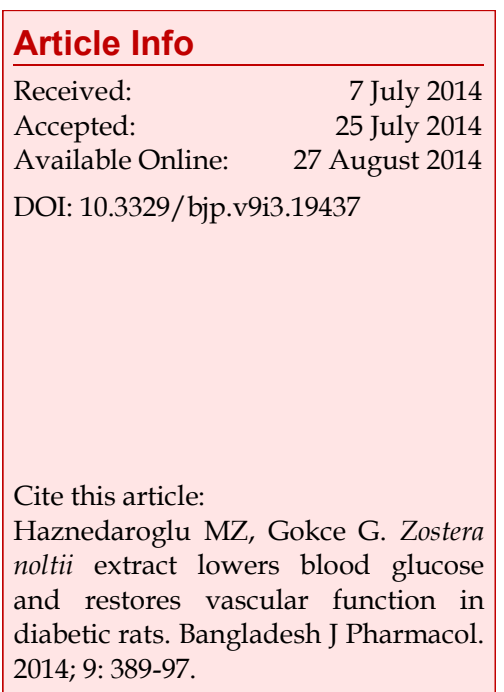

\begin{abstract}
The antidiabetic effect of seagrass Zostera noltii extract was investigated through a crosstalk between its anti-oxidant and vasoprotective properties. The extract was orally administered to alloxan-diabetic rats $(50,150,250 \mathrm{mg} /$ $\mathrm{kg}$ body weight). Serum glucose was determined; liver and kidney functions, body weight, total leukocyte counts were measured; liver oxidative markers were assayed. Acetylcholine, phenylephrine and 5-HT responses were tested. eNOS levels and generation of ROS in aortic tissue were quantified. The extract of $Z$. noltii lowered blood glucose in all tested dose levels. Extract at a concentration of $50 \mathrm{mg} / \mathrm{kg}$ failed to preserve the levels of anti-oxidants and did not alter lipid peroxidation whereas higher doses improved liver oxidative status. Impaired acetylcholine relaxations, augmented phenylephrine and 5-HT contractions in alloxan-diabetic aortic rings were restored by $Z$. noltii treatment. This recovery was accompanied by increased eNOS synthesis and a reduction in ROS generation. The extract lowers blood glucose and prevents hyperglycemia-induced endothelial dysfunction in alloxan-diabetic rats.
\end{abstract}

\section{Introduction}

Diabetes mellitus is a life-threatening metabolic disorder of multiple etiology. Oxidative stress has been recognized as a critical player in the pathogenesis of diabetes (Murugan and Pari, 2006). Furthermore, chronic hyperglycemia itself, enhances the production of reactive oxygen species (ROS) by glucose autooxidation and/or non-enzymatic protein glycosylation (Giugliano et al., 1996; Signorini et al., 2002). Elevated oxidants and markers for oxidative tissue damage have been well documented in patients with diabetes (Rehman et al., 1999; Chowienczyk et al., 2000; Fava et al., 2002; Zitouni et al., 2005). Therefore, anti-oxidants gained considerable attention in prevention of diabetes and its micro- and macro-vascular complications which are regarded as the most common reasons of morbidity and mortality (Guo et al., 2005; Gokce and Hazneda- roglu, 2008).

While a damaged endothelium is the starting point to diabetic macroangiopathy, impairments in endothelium - and nitric oxide (NO)-dependent micro-vascular function, may contribute to several other corollaries of diabetes, such as hypertension, dyslipi-demia and insulin resistance (Laight et al., 1999). Anti-oxidant therapy may conceivably confer both cardio-vascular and metabolic benefits in diabetes. This notion is well grounded in the theory surrounding the role of oxidative stress in disease and supported by evidence of reduced anti-oxidant defenses in diabetes and also by experimental findings that anti-oxidants improve endothelium-dependent vasodilation and insulin sensitivity (Laight et al., 1999). Moreover, there is an increasing demand by patients to use natural anti-diabetic products due to undesirable side effects of insulin and 
oral hypoglycemic drugs (Rao and Rao, 2001; Gong et al., 2012; Mohan et al., 2014)

Zostera noltii Hornemann (Zosteraceae) is a perennial phanerogam with small leaves growing permanently submerged. It is distributed in shallow sheltered sea bays from the southern coasts of Norway to the Mediterranean Sea, the Black Sea, besides Northwest Africa coasts (Mireia et al., 2011). As with other seagrasses, $Z$. noltii plays important roles in marine ecosystems for biodiversity, ecological, sedimentary and economic reasons (Rende et al., 2012). Seagrasses are thought to be chemically defended against herbivores and pathogenic infections such as wasting disease by phenolic compounds (Grignon-Dubois et al., 2012). Z. noltii is rich in phenolic compounds and flavonoids such as, chlorogenic acid, caffeic acid, rosmarinic acid zosteric acid, apigenin, diosmetin, luteolin and luteolin-7-Oglucoside (Lamaison et al., 1990; Zeljan and Misko, 2000; Achamlale et al., 2009; Newberry et al., 2011; Sato et al., 2011). Additionally, crude extracts of seagrasses are shown to exert antibacterial, antifungal, antiviral, anti-oxidant, anti-inflammatory, anti-diabetic and anticancer activities (Papenbrock, 2012). Moreover, we have shown that total extract of another seagrass, Posidonia oceanica has anti-oxidant, antidiabetic and vasoprotective effects (Gokce and Haznedaroglu, 2008). Present study aims to investigate the glucose lowering activity of $Z$. noltii in alloxan-induced diabetes, through a crosstalk between its anti-oxidant and vasoprotective properties.

\section{Materials and Methods \\ Plant material \\ Z. noltii was collected from Urla, Izmir, Aegean Sea in October 2011 at $1 \mathrm{~m}$ depth. The plant was identified at the Department of Pharmaceutical Botany, Faculty of Pharmacy, Ege University, Izmir and specimen vou- chers are kept at IZEF Herbarium (IZEF5887). The epiphytes on the leaves were removed with paper towel without damaging the organs. Leaves were dried in shadow and at controlled room conditions $\left(25^{\circ} \mathrm{C}\right)$.}

\section{Extraction}

Chopped leaves were infused with aqueous ethanol $50 \%(\mathrm{v} / \mathrm{v})$ for 3 hours in a water bath at $40^{\circ} \mathrm{C}$ with a reflux system. Homogenate was filtered and acidified $(\mathrm{pH}=3)$ with HCI. Ethanol was evaporated under vacuum at $45^{\circ} \mathrm{C}$. Obtained aqueous residue was extracted with ethyl acetate. Water is removed from organic phase with anhydrous sodium sulfate, filtered and evaporated under vacuum. Dry samples were prepared following filtration, evaporation and lyophilizetion. After 25 repetitions with overall $1.2 \mathrm{~kg}$ of plant material $24 \mathrm{~g}$ of extract was obtained (Cuny et al., 1995).

\section{Chemicals}

All drugs were purchased from Sigma (USA). Solvents used in extraction procedure were purchased from Labscan (Ireland), while hydrochloric acid and anhydrous sodium sulfate were from Riedel Haen (Germany).

\section{Animals}

Three-month-old male Wistar rats (200-225 g; $\mathrm{n}=30$; Lemali Ltd, Ankara, Turkey) were used. Animals were maintained under $22 \pm 2^{\circ} \mathrm{C}$ and a 12 hours light/dark cycle day and had unrestricted access to pelleted food and water. At end of the experimental protocol final body weights were recorded and animals were killed by means of an overdose of sodium pentobarbital.

\section{Glucose tolerance}

Rats were fasted overnight and rando-mized to three groups $(\mathrm{n}=6)$. Control group received $1 \mathrm{~mL}$ of distilled water orally (Group I). Z. noltii was administered at concentrations of $100,500 \mathrm{mg} / \mathrm{kg}$ (p.o, Groups II and III, respectively). Following Z noltii administration, all groups received glucose (p.o, $2 \mathrm{~g} / \mathrm{kg}$ ). Blood samples were taken from the tail vein just prior to and 30,60, 120 and $240 \mathrm{~min}$ after glucose loading. Glucose was assayed by glucose oxidase method (Trinder, 1976). Data obtained from glucose tolerance test were used as a hypothetical reference to determine the dose level which will be used in evaluation of short- and longterm effects of $Z$. noltii on diabetic rats.

\section{Antidiabetic effects}

Diabetes was induced by a single intraperitoneal injection of alloxan monohydrate $(120 \mathrm{mg} / \mathrm{kg})$ (Cooperstein and Walkins, 1981). After 72 hours, animals with glucose levels higher than $250 \mathrm{mg} / \mathrm{dL}$ were considered diabetic (Perfumi and Tacconi, 1996) and randomized to five groups $(n=6)$. Group I (no alloxan treatment) and Group II (diabetic control) rats were given $1 \mathrm{~mL}$ of distilled water. Groups III-V received aqueous suspension of $Z$. noltii on the $3^{\text {rd }}$ day after alloxan administration (respectively, p.o, 50, 100, and $150 \mathrm{mg} / \mathrm{kg}$ ). Blood samples were taken from the tail vein (fasted rats) just prior to administration of the extract and at 2, 4,6 and 8 hours intervals. Serum was separated and glucose levels were estimated. These rats were given the same doses of the extract once daily for 15 days in the multidose study. Blood (non-fasted rats) was taken on $6,9,12,15$ and $18^{\text {th }}$ day after alloxan administration (Sabu et al., 2002) and serum glucose levels were measured as mentioned above.

\section{Liver and kidney functions}

Alkaline phosphatase (ALP) (King et al., 1980), glutamate pyruvate transaminase (GPT) (Bergmeyer et al., 1980), blood urea nitrogen (BUN) (Haslam et al., 1966), and creatinine (Brod et al., 1948) were measured. 
Protein content was determined by the method of (Lowry et al., 1951). Total white blood cell count was determined using a hemocytometer.

\section{Anti-oxidant status}

In liver homogenates, reduced glutathione (GSH), glutathione peroxidase (GPx), superoxide dismutase (SOD), catalase, and malondialdehyde (MDA levels) were determined spectrophotometrically (Victor III; Perkin Elmer, Finland) using commercially available assay kits and according to the manufacturer's instructions (Bioxytech GSH-412, GPx-340, SOD-525, Catalase520, and MDA-586, respectively; Oxis International, USA). Total nitrite in aortic tissue was estimated colorimetrically using Griess reagent (Guevara et al., 1998). Nitrite concentration in the sample was calculated using sodium nitrite as standard and normalized to the protein content of aorta.

\section{Effects of extract on vascular responses}

Aortic rings $(2 \mathrm{~mm})$ were mounted under $2 \mathrm{~g}$ resting tension on stainless steel hooks within $25 \mathrm{~mL}$ tissue baths and maintained at $37^{\circ} \mathrm{C}$ in Krebs solution (mM): $\mathrm{NaCl}, 118 ; \mathrm{KCl}, 4.7 ; \mathrm{CaCl}_{2} \cdot 2 \mathrm{H}_{2} \mathrm{O}, 2.5 ; \mathrm{KH}_{2} \mathrm{PO}_{4}, 1.20$; $\mathrm{MgSO}_{4} \cdot 7 \mathrm{H}_{2} 0$, 1.17; Glucose, 11.1; $\mathrm{NaHCO}_{3}, 25$, gassed with $95 \% \mathrm{O}_{2}$ and $5 \% \mathrm{CO}_{2}$. Tension was recorded isometrically by a data acquisition system (Biopac, MP100) equipped with a Grass FT03 transducer. Vascular reactivity studies were performed as previously described (Gokce and Haznedaroglu, 2008).

\section{Reactive oxygen species}

Levels of superoxide anion and other reactive species in aortic rings were determined according to the method described by Wang et al. (2001), with slight modifications. $2 \mathrm{~mm}$ cut aortic segments were placed in a 96 well plate containing PBS-HEPES buffer (0.5 M PBS containing $20 \mathrm{mM}$ HEPES, pH 7.4). After addition of chemiluminescence enhancers, lucigenin or luminol (final concentration of $5 \mu \mathrm{mol} / \mathrm{L}$ for either), ROS were quantified using a multi-plate reader (Victor III-1420, Perkin Elmer, Finland). Results were corrected for wet tissue weight and expressed as relative light units rlu/ mg tissue) (Haklar et al., 2003).

\section{Determination of endothelial nitric oxide synthase (eNOS)}

Endothelial nitric oxide synthase levels in aortic tissue was determined using a commercially available ELISA kit (USCNlife, USA) according to the manufacturer's instructions. Optical density was measured at $450 \mathrm{~nm}$ using a microplate reader (Victor III-1420, Perkin Elmer, Finland). A standard linear regression curve was generated and the concentration of each sample was calculated by the curve equation.

\section{Statistical analysis}

Data are expressed as the mean \pm S.E. Student's t-test for unpaired samples (GraphPad Prism, Version 3.02, USA). A value of $\mathrm{p}<0.05$ was considered significant. Agonist stimulated vasoactivity was evaluated in means of maximal effect $\left(E_{\max }\right)$ and $\mathrm{pD}_{2}$ (negative logarithm of the concentration that produced half of the $E_{\max }$, as a measure of sensitivity) values. Acetylcholine-

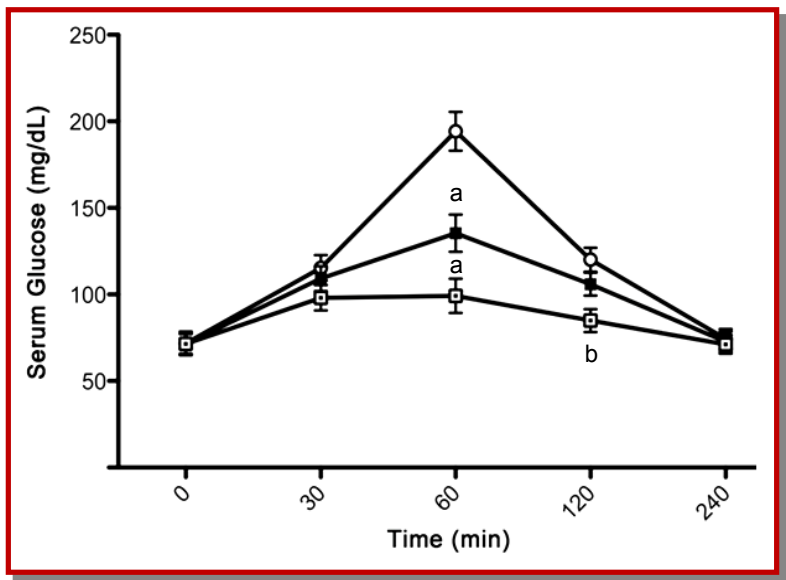

Figure 1: Effects of Z. noltii extract on glucose tolerance. Glucose levels obtained from Group I (control) (i); Group II (Z. noltii extract $100 \mathrm{mg} / \mathrm{kg}$ ) (<); and Group III (Z. noltii extract $500 \mathrm{mg} / \mathrm{kg}$ ) (o) are shown. Data are expressed as mean \pm S.E. $\left({ }^{a} p<0.01\right.$, compared to control at $60 \mathrm{~min}$ and ${ }^{\mathrm{b}} \mathrm{p}<0.05$ compared to control at $120 \mathrm{~min} ; \mathrm{n}=6$

induced relaxant responses were normalized by the initial phenylephrine contraction. Contractile responses to phenylephrine and 5-HT were normalized with maximal contractions induced by potassium chloride.

\section{Results}

Sixty min after glucose loading, serum glucose level of $71.7 \pm 6.8 \mathrm{mg} / \mathrm{dL}$ increased up to $198.0 \pm 8.1 \mathrm{mg} / \mathrm{dL}$ and returned to baseline at $240 \mathrm{~min}$. Z. noltii extract improved glucose tolerance in a dose-dependent manner (Figure 1, ap $<0.01$; control vs. Z. noltii-100 and $Z$. noltii-100 vs. Z. noltii-500). Effect of the extract on glucose tolerance at the dose level of $500 \mathrm{mg} / \mathrm{kg}$ remained statistically significant at $120 \mathrm{~min}$ (Figure 1, ${ }^{\mathrm{b}} \mathrm{p}<0.05$; control vs. Z. noltii-500).

In the single dose study, effects of $Z$. noltii extract on blood glucose levels were evaluated on the $3^{\text {rd }}$ day after alloxan administration. Z. noltii extract $(50 \mathrm{mg} / \mathrm{kg}) \mathrm{did}$ not reduce serum glucose. At dose levels of 150 and 250 $\mathrm{mg} / \mathrm{kg}$, glucose levels were decreased by 24.8 and $29.9 \%$ at the $6^{\text {th }}$ hour, respectively. Antidiabetic effect of the extract was slightly decreased at the $8^{\text {th }}$ hour, but remained statistically significant (Table I).

In parallel experiments, Z. noltii extract was administered to diabetic rats for 15 days at aforementioned doses (Table II). Z. noltii extract $(50 \mathrm{mg} / \mathrm{kg})$ started to lower serum glucose on the $9^{\text {th }}$ day and an overall reduc 


\section{Table I}

Effects of Z. noltii extract (single dose) on serum glucose levels in alloxan-induced diabetic rats

\begin{tabular}{|c|c|c|c|c|c|c|}
\hline \multirow[t]{2}{*}{ Group } & \multirow[t]{2}{*}{ Treatment (mg/kg) } & \multicolumn{5}{|c|}{ Serum glucose $(\mathrm{mg} / \mathrm{dL})$} \\
\hline & & 0 hour & 2 hour & 4 hour & 6 hour & 8 hour \\
\hline I & Normal & $71.7 \pm 6.8$ & $68.4 \pm 7.1$ & $65.2 \pm 8.1$ & $68.6 \pm 8.3$ & $70.3 \pm 8.1$ \\
\hline II & Control (alloxan) & $269.1 \pm 11.7 \mathrm{a}$ & $275.3 \pm 10.9 a$ & $278.2 \pm 12.1^{a}$ & $274.3 \pm 9.2^{\mathrm{a}}$ & $268.6 \pm 8.8^{a}$ \\
\hline III & Z. noltii extract (50) & $262.6 \pm 10.8$ & $265.6 \pm 9.8$ & $259.4 \pm 9.7$ & $256.4 \pm 11.1$ & $253.7 \pm 9.9$ \\
\hline IV & Z. noltii extract (150) & $259.3 \pm 9.7$ & $254.2 \pm 9.3$ & $238.6 \pm 8.8$ & $206.1 \pm 10.4^{b}$ & $215.4 \pm 10.2^{c}$ \\
\hline $\mathrm{V}$ & Z. noltii extract (250) & $255.1 \pm 12.1$ & $243.1 \pm 11.1$ & $231.7 \pm 9.1$ & $192.4 \pm 9.6^{b}$ & $199.5 \pm 9.7^{b}$ \\
\hline
\end{tabular}

\section{Table II}

Effects of Z. noltii extract (daily treatment) on serum glucose levels in alloxan-induced diabetic rats

\begin{tabular}{|c|c|c|c|c|c|c|c|}
\hline \multirow[t]{2}{*}{ Group } & \multirow{2}{*}{$\begin{array}{l}\text { Treatment } \\
(\mathrm{mg} / \mathrm{kg})\end{array}$} & \multicolumn{6}{|c|}{ Serum glucose $(\mathrm{mg} / \mathrm{dL})$} \\
\hline & & 3 days & 6 days & 9 days & 12 days & 15 days & 18 days \\
\hline I & Normal & $73.7 \pm 6.1$ & $71.6 \pm 7.5$ & $70.1 \pm 9.4$ & $72.9 \pm 7.6$ & $69.6 \pm 5.6$ & $73.8 \pm 7.1$ \\
\hline II & Control (alloxan) & $271.2 \pm 11.8^{2}$ & $278.2 \pm 10.4^{2}$ & $270.3 \pm 10.4^{2}$ & $272.5 \pm 9.8^{2}$ & $267.4 \pm 9.9^{2}$ & $261.8 \pm 8.3^{2}$ \\
\hline III & Z. noltii extract (50) & $268.7 \pm 9.7$ & $248.4 \pm 9.8$ & $229.3 \pm 8.2^{*}$ & $217.3 \pm 7.9^{*}$ & $207.5 \pm 8.7^{*}$ & $198.5 \pm 7.9^{*}$ \\
\hline IV & Z. noltii extract (150) & $274.1 \pm 8.5$ & $230.2 \pm 9.3$ & $209.9 \pm 11.1^{* *}$ & $173.1 \pm 8.8^{* * *, a}$ & $149.8 \pm 9.5^{* * *, \mathrm{~b}}$ & $130.2 \pm 10.2^{+, c}$ \\
\hline $\mathrm{V}$ & Z. noltii extract (250) & $270.3 \pm 9.4$ & $219.5 \pm 8.1^{\text {** }}$ & $165.2 \pm 9.9^{* \star *}$ & $140.2 \pm 7.6^{+, \mathrm{d}}$ & $129.6 \pm 8.4^{+, \mathrm{e}}$ & $103.4 \pm 11.1^{+, \mathrm{f}}$ \\
\hline
\end{tabular}

\section{Table III}

\section{Effects of Z. noltii extract on liver and kidney functions}

\begin{tabular}{|c|c|c|c|c|}
\hline \multirow[t]{2}{*}{ Treatment (mg/kg) } & Liver & Liver & Kidney & Kidney \\
\hline & $\operatorname{ALP}(\mathrm{KA} / \mathrm{dL})$ & GPT (U/mg protein) & BUN (mg/dL) & Creatinine $(\mathrm{mg} / \mathrm{dL})$ \\
\hline Normal & $33.7 \pm 2.8$ & $159.4 \pm 10.1$ & $9.2 \pm 0.6$ & $0.7 \pm 0.0$ \\
\hline Control (alloxan) & $50.3 .1 \pm 6.7 \mathrm{a}$ & $335.3 \pm 21.9 \mathrm{~b}$ & $19.3 \pm 2.2 c$ & $2.1 \pm 0.1^{c}$ \\
\hline Z. noltii extract (50) & $42.6 \pm 4.8$ & $285.6 \pm 19.8$ & $16.4 \pm 11.1$ & $1.7 \pm 0.1$ \\
\hline Z. noltii extract (150) & $35.3 \pm 2.7 \mathrm{e}$ & $244.2 \pm 12.3^{e}$ & $13.6 \pm 0.7^{f}$ & $1.5 \pm 0.0^{\mathrm{e}}$ \\
\hline Z. noltii extract (250) & $31.1 \pm 12.1^{f}$ & $206.1 \pm 9.1^{f}$ & $11.5 \pm 0.6 \mathrm{~g}$ & $1.2 \pm 0.0 \mathrm{~g}$ \\
\hline
\end{tabular}

\section{Table IV}

\section{Effects of Z. noltii extract on body weight, total leucocyte count and liver glycogen}

\begin{tabular}{|c|c|c|c|c|}
\hline \multirow[t]{2}{*}{ Treatment $(\mathrm{mg} / \mathrm{kg})$} & \multicolumn{2}{|c|}{ Body weight } & \multirow{2}{*}{$\begin{array}{l}\text { Total leukocyte count } \\
\qquad\left(\mathrm{mm}^{3}\right)\end{array}$} & \multirow{2}{*}{$\begin{array}{l}\text { Liver glycogen } \\
(\mu \mathrm{g} / \mathrm{g} \text { tissue })\end{array}$} \\
\hline & Initial & Final & & \\
\hline Normal & $241.7 \pm 7.8$ & $259.4 \pm 9.1$ & $13234.6 \pm 456.7$ & $76.9 \pm 4.6$ \\
\hline Control (alloxan) & $245.3 \pm 9.6$ & $205.3 \pm 21.9 a$ & $8567.2 \pm 389.2^{c}$ & $58.1 \pm 4.8^{\mathrm{d}}$ \\
\hline Z. noltii extract (50) & $249.6 \pm 10.1$ & $245.6 \pm 19.8^{b}$ & $9453.6 \pm 511.2$ & $67.7 \pm 4.1$ \\
\hline Z. noltii extract (150) & $243.3 \pm 8.1$ & $249.2 \pm 12.3$ & $11103.6 \pm 658.1 \mathrm{e}$ & $74.5 \pm 5.1 \mathrm{e}$ \\
\hline Z. noltii extract (250) & $247 \pm 12.1$ & $263.1 \pm 9.11$ & $13002.5 \pm 703.1^{\mathrm{f}}$ & $77.6 \pm 5.5 \mathrm{e}$ \\
\hline
\end{tabular}




\begin{tabular}{|c|c|c|c|c|c|}
\hline \multicolumn{6}{|c|}{ Table V } \\
\hline \multicolumn{6}{|c|}{ Effects of Z. noltii extract on oxidative status } \\
\hline Parameter & Normal & $\begin{array}{l}\text { Control } \\
\text { (alloxan) }\end{array}$ & $\begin{array}{l}\text { Z. noltii extract } \\
(50 \mathrm{mg})\end{array}$ & $\begin{array}{l}\text { Z. noltii extract } \\
(150 \mathrm{mg})\end{array}$ & $\begin{array}{l}\text { Z. noltii extract } \\
(250 \mathrm{mg})\end{array}$ \\
\hline GSH (nmol/mg protein) & $7.4 \pm 0.4$ & $4.2 \pm 0.2^{c}$ & $4.5 \pm 0.3$ & $5.9 \pm 0.4^{*}$ & $6.3 \pm 0.4^{* * *}$ \\
\hline GSSG (nmol/mg protein) & $0.3 \pm 0.0$ & $0.9 \pm 0.1 \mathrm{c}$ & $0.7 \pm 0.1$ & $0.6 \pm 0.1^{*}$ & $0.3 \pm 0.1^{* * *}$ \\
\hline GPx (U/mg protein) & $0.2 \pm 0.0$ & $0.1 \pm 0.0^{\mathrm{a}}$ & $0.1 \pm 0.0$ & $0.1 \pm 0.0^{*}$ & $0.2 \pm 0.1^{*}$ \\
\hline MDA (nmol/mg tissue) & $354.2 \pm 10.2$ & $442.2 \pm 14.9^{b}$ & $422.3 \pm 13.1$ & $390.2 \pm 9.2^{*}$ & $355.6 \pm 11.6^{* *}$ \\
\hline SOD (U/mg protein) & $6.3 \pm 0.4$ & $3.3 \pm 0.3 c$ & $3.6 \pm 0.3$ & $4.4 \pm 0.6^{* *}$ & $5.6 \pm 0.5^{* * *}$ \\
\hline Catalase (U/mg protein) & $153.6 \pm 6.7$ & $98.3 \pm 7.0^{\mathrm{b}}$ & $119.2 \pm 8.3$ & $126.2 \pm 7.5^{*}$ & $142.7 \pm 10.6^{* *}$ \\
\hline \multicolumn{6}{|c|}{$\begin{array}{l}\text { GSH: reduced glutathione, GSSG: oxidized glutathione; GPx: glutathione peroxidase, MDA: malondialdehyde; SOD: superoxide dismutase. Data } \\
\text { are expressed as mean } \pm \mathrm{S} . \mathrm{E} ; \mathrm{n}=6 \text {; } \mathrm{a}<0.01, \mathrm{~b}<0.001, \mathrm{p}<0.0001 \text { and " } \mathrm{p}<0.01 \text { (compared to normal group); } \mathrm{p}<0.05 \text { and }{ }^{* * *} \mathrm{p}<0.001 \text { (compared to } \\
\text { control group) }\end{array}$} \\
\hline
\end{tabular}

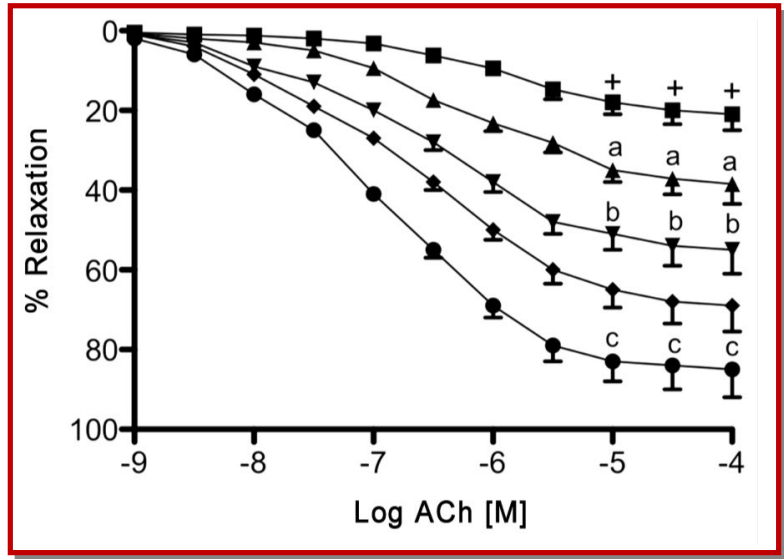

Figure 2: Effects of Z. noltii extract on acetylcholine relaxations in alloxan diabetic rats. Concentration-response curves obtained from Group I (normal) (l); Group II (diabetic control) (n); Group III (Z. noltii extract $50 \mathrm{mg} / \mathrm{kg})(\mathbf{\Lambda})$; Group IV (Z. noltii extract $150 \mathrm{mg} / \mathrm{kg}$ ) ( $\mathbf{\nabla})$; and Group V (Z. noltii extract 250 $\mathrm{mg} / \mathrm{kg})(i)$ are shown. Data are expressed as mean \pm S.E; $\left({ }^{+} \mathrm{p}<0.0001\right.$; compared to normal group, a $\mathrm{p}<0.01,{ }^{b} \mathrm{p}<0.001$ and $c p<0.0001 ;$ compared to diabetic control group; $n=6$

-tion of $26 \%$ was observed on the $18^{\text {th }}$ day $(p<0.01)$. At dose level of $150 \mathrm{mg} / \mathrm{kg}$, serum glucose was found to decrease by $52.5 \%$ on the $18^{\text {th }}$ day $(p<0.0001)$. The effect of the extract was more pronounced at $250 \mathrm{mg} / \mathrm{kg}$, starting on the $6^{\text {th }}$ day with a reduction rate of $18.9 \%$ $(p<0.01)$ and and finally reaching to its maximum on the $18^{\text {th }}$ day by $61.9 \%$. Between the $12^{\text {th }}$ and $18^{\text {th }}$ days, antidiabetic effect of Z. noltii extract was in a concentration dependent manner (Table II).

Table III summarizes the effects of $Z$. noltii extract on hepatic and renal function in alloxan-diabetic rats. As seen, treatment with $50 \mathrm{mg} / \mathrm{kg}$ did affect neither the significantly high levels of ALP, GPT, BUN and creatinine, nor the overall oxidative status. Conversely, rats treated with higher doses of the extract (150 and 250 $\mathrm{mg} / \mathrm{kg}$ ) showed significant improvements in hepatic and renal function (Table III). Additionally, these two dose levels recovered the weight loss and low white blood cell count observed in alloxan-diabetic rats while decreasing liver glycogen (Table IV). Z. noltii extract (150 and $250 \mathrm{mg} / \mathrm{kg}$ ) also showed a protective effect on liver oxidative status (Table V). Anti-oxidants namely GSH, GPx, SOD and catalase were increased by Z. noltii extract administration. When compared to alloxandiabetic rats, MDA formation, as an indirect measure of lipid peroxidation, was found to be significantly low in high dose Z. noltii extract-treated rats (Table V).

Table VI

Effects of Z. noltii extract on acetylcholine, phenylephrine and 5-HT-induced vascular responses

\begin{tabular}{llrrrrrr} 
Group & Treatment $(\mathrm{mg} / \mathrm{kg})$ & \multicolumn{6}{c}{ Acetylcholine } \\
\cline { 3 - 8 } & & \multicolumn{1}{c}{$\mathrm{E}_{\max }$} & \multicolumn{1}{c}{$\mathrm{pD}_{2}$} & \multicolumn{1}{c}{$\mathrm{E}_{\max }$} & \multicolumn{1}{c}{$\mathrm{pD}_{2}$} & \multicolumn{1}{c}{$\mathrm{E}_{\operatorname{maks}}$} & \multicolumn{1}{c}{$\mathrm{pD}_{2}$} \\
\hline I & Normal & $85.1 \pm 7.3$ & $6.9 \pm 0.08$ & $146.1 \pm 12.1$ & $6.2 \pm 0.06$ & $126.1 \pm 8.1$ & $5.9 \pm 0.04$ \\
II & Control (alloxan) & $21.2 \pm 4.2^{\mathrm{a}}$ & $5.9 \pm 0.05^{\mathrm{a}}$ & $370.2 \pm 24.2^{\mathrm{a}}$ & $6.8 \pm 0.06^{\mathrm{a}}$ & $280.2 \pm 14.2^{\mathrm{a}}$ & $6.6 \pm 0.05^{\mathrm{a}}$ \\
III & Z. noltii extract (50) & $38.5 \pm 5.1^{*}$ & $6.3 \pm 0.06^{*}$ & $278.3 \pm 15.2^{*}$ & $6.5 \pm 0.05^{\mathrm{d}}$ & $227.3 \pm 10.2^{*}$ & $6.5 \pm 0.03$ \\
IV & Z. noltii extract (150) & $55.2 \pm 6.2^{* *, \mathrm{~b}}$ & $6.5 \pm 0.05^{* *, \mathrm{~b}}$ & $226.3 \pm 11.4^{* *, \mathrm{~b}}$ & $6.4 \pm 0.03^{\mathrm{d}}$ & $180.4 \pm 9.1^{* *, \mathrm{~b}}$ & $6.3 \pm 0.04$ \\
V & Z. noltii extract (250) & $69.3 \pm 6.5^{* * *, \mathrm{c}}$ & $6.8 \pm 0.04^{* * *, \mathrm{c}}$ & $177.4 \pm 8.5^{* * *, \mathrm{c}}$ & $6.3 \pm 0.03^{*}$ & $130.2 \pm 8.3^{* * *, \mathrm{c}}$ & $6.2 \pm 0.05^{*}$
\end{tabular}

$\mathrm{E}_{\max }$ : maximal effect; $\mathrm{pD}_{2}$ : negative logarithm of the concentration that produced half of the $\mathrm{E}_{\max }$. Data are expressed as mean $\pm \mathrm{S}$.E: $\mathrm{n}=6$;

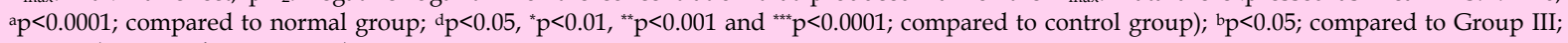
c $\mathrm{p}<0.05$ (compared to Group IV) 


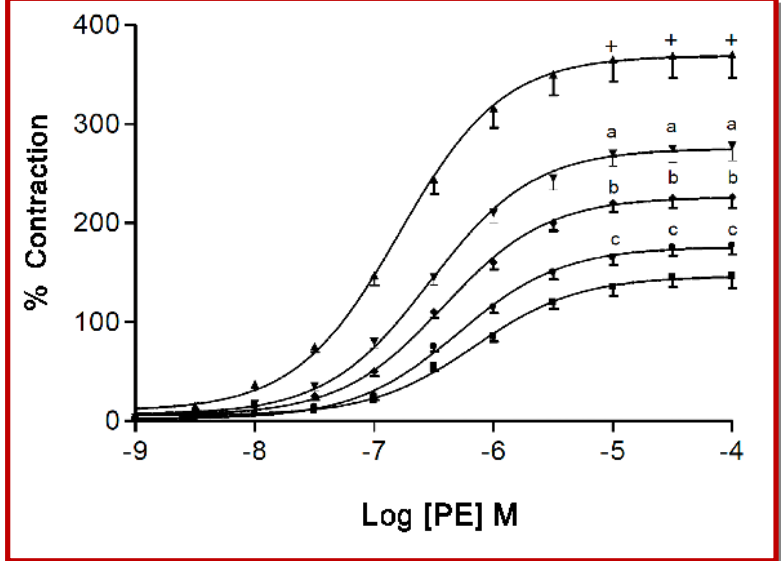

Figure 3: Effects of Z. noltii extract on phenylephrine contractions in alloxan diabetic rats. Concentration-response curves obtained from Group I (normal) (n); Group II (diabetic control) (४); Group III (Z. noltii extract $50 \mathrm{mg} / \mathrm{kg})(\mathbf{\nabla})$; Group IV (Z. noltii extract $150 \mathrm{mg} / \mathrm{kg}$ ) (i); and Group V (Z. noltii extract 250 $\mathrm{mg} / \mathrm{kg})(=)$ are shown. Data are expressed as mean \pm S.E. $\left({ }^{+} \mathrm{p}<0.0001\right.$; compared to normal group; ${ }^{\mathrm{a}} \mathrm{p}<0.01,{ }^{\mathrm{b}} \mathrm{p}<0.001$ and ${ }^{c} \mathrm{p}<0.0001 ;$ compared to diabetic control group; $n=6$

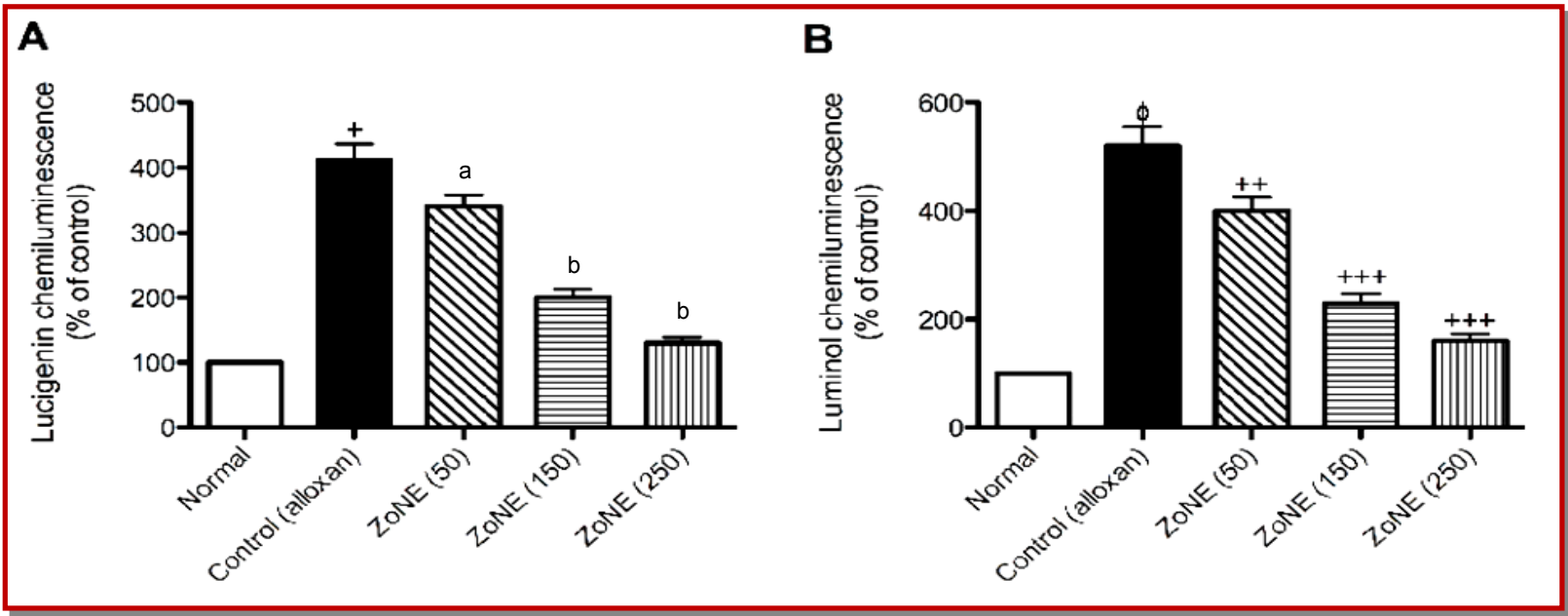

Figure 5: Lucigenin (A) and luminol (B) -enhanced chemiluminescence in rat thoracic aorta. Results are expressed as mean \pm standard error of mean of area under curve (AUC) for a counting period of $5 \mathrm{~min} n=6$, AUC of relative light units (rlu)/mg wet tissue (as \% of normal values). ${ }^{+,} \mathrm{p}<0.001$ indicates a significant difference in the production of superoxide anion or other ROS from normal group; ${ }^{a} \mathrm{p}<0.05$ and ${ }^{\mathrm{b}} \mathrm{p}<0.001$ indicate a significant reversal of the increased superoxide anion production by $\mathrm{Z}$. noltii extract. ${ }^{++} \mathrm{p}<0.01$ and ${ }^{+++} \mathrm{p}<0.001$ indicate a significant reversal of the increased ROS production by Z. noltii extract

In order to evaluate the effects of Z. noltii extract on vascular responses, cumulative concentration-response curves for acetylcholine, phenylephrine and 5-HT were obtained in thoracic aorta. Z. noltii extract treatment, at all tested dose levels, recovered the impaired acetylcholine relaxations observed in alloxan-diabetic rats (Figure 2) and resulted in a concentration-dependent increase in sensitivity (Table VI). Addition-ally, contractile responses to phenylephrine (Figure 3) and 5HT (Figure 4) which were significantly augmented in hyperglycemic rats were dose-dependently ate-nuated by Z. noltii extract treatment (Table VI). These changes in vascular reactivity by $Z$. noltii extract treatment were accompanied by significant alterations in ROS production in rat aorta. Lucigenin- and luminol-enhanced chemiluminescences in alloxan-diabetic aorta- were approximately 4 and 5 times higher than in those of control tissues, respectively (Figure 5A and B). Starting from the lowest dose, Z. noltii extract, significantly inhibited superoxide anion generation and forma-tion of other reactive species (Figure 5A and B). Moreover, concentrations of eNOS in aortae from Z $\mathrm{Z}$. noltii extract treated diabetic rats were significantly higher when compared to diabetic control (Figure 6A). On the other hand, total nitrite levels in aorta were found to be similar among experimental groups (Figure 6B). 


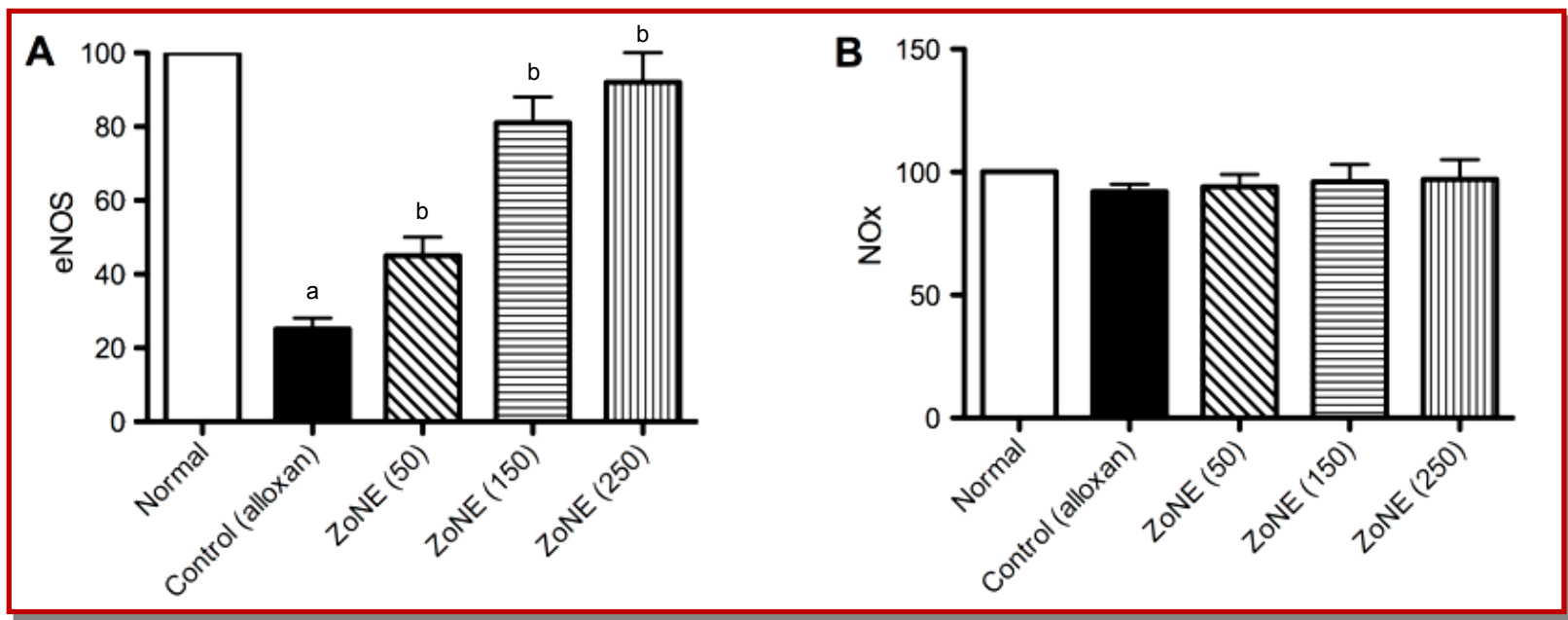

Figure 6: eNOS (A) and NOx (B) levels in rat thoracic aorta. Results are expressed as mean \pm S.E; $n=6$, as \% of normal values; ${ }^{a} \mathrm{p}<0.001$ indicates a significant difference from normal group; ${ }^{b} \mathrm{p}<0.001$ indicate a significant increase in eNOS levels in comparison with control (alloxan) group

\section{Discussion}

In the present study, we for the first time demonstrate that Z. noltii extract lowers blood glucose and protects vascular endothelium from the harmful effects of hyperglycemia in alloxan-diabetic rats. As is known, alloxan increases production of reactive oxygen species (ROS) leading to cytotoxicity in pancreatic $\beta$-cells, and thereby inhibits insulin activity while affecting major organs and haemopoietic system (Sakurai et al., 2001; Sabu et al., 2002). Additionally, alloxan impairs endothe -lium-dependent vasorelaxation and increases contractile responses to agonists such as phenylephrine and 5HT (Gokce and Haznedaroglu, 2008). Our results indica -ted that administration of Z $\mathrm{Z}$. noltii extract to alloxandiabetic rats lowers blood glucose and recovers vascular endothelial function in a dose-dependent manner. Also, at dose levels of 150 and $250 \mathrm{mg} / \mathrm{kg}, \mathrm{Z}$. noltii extract improves oxidant status and inhibits lipid peroxidation. Since pancreatic tissue damage mediated by lipoxygenase-derived peroxides is closely related with insulin secretion (Metz, 1984; Walsh and Pek, 1984), we firstly hypothesized that glucose lowering activity of $Z$. noltii extract would be related to its antioxidant effects. However, Z. noltii extract $50 \mathrm{mg} / \mathrm{kg}$, while showing significant antidiabetic activity, failed to preserve the levels of anti-oxidants and did not alter lipid peroxidation. Taking the above debate into consideration, it is conceivable that antidiabetic effects of $Z$. noltii extract may possibly not only be related to its antioxidant properties.

Endothelial dysfunction which can be defined as loss of the balance between vasoconstrictors and vasodilators, is a major complication of diabetes and a well-documented phenomenon in various experimental models of hyperglycemia (Oyama et al., 1986; Meraji et al., 1987; Shukla et al., 2004; Gokce and Haznedaroglu, 2008). Increased superoxide anion $\left(\mathrm{O}_{2}{ }^{-}\right)$generation and hydrogen peroxide $\left(\mathrm{H}_{2} \mathrm{O}_{2}\right)$ accumulation have been demonstrated to decrease agonist-stimulated activity of nitric oxide (NO) in diabetic aorta (Karasu, 2000). In the present study, Z. noltii extract, at all tested dose levels, restored acetylcholine relaxations and increased $\mathrm{pD}_{2}$ values in a concentration-dependent manner. This recovery by $Z$. noltii extract was completely inhibited by the NO synthase inhibitor L-NAME (data not shown), ruling out the possibility that $Z$. noltii extract causes vasodilation by directly affecting vascular smooth muscle. These findings have given rises to the question whether protective effect of $Z$. noltii extract on endothelium-dependent relaxation may be related to alterations in NO bioavalibility and/or eNOS synthesis. It has been previously shown that polyphenolic compounds in red wine activates eNOS via PI3K pathway (Ndiaye et al., 2005). Also, Hancornia speciosa extract which is rich in polyphenolics was shown to produce NO-dependent vasorelaxation in rat aorta (Ferreira et al., 2007). Moreover, Posidonia ocenica, another seagrass widely allocated in the Mediterrenean Sea, has been shown to lower blood glucose and prevent hyperglycemia-induced endothelial dysfunction in a similar pattern (Gokce and Haznedaroglu, 2008). Taking into consideration that phosphatidyl-inositol 3-kinase (PI3K) pathway is crucial to many of the effects of insulin (Epstein, 1999), we have therefore measured eNOS and total nitrite (NOx) levels in aortic tissue. While not affecting NOx, $Z$. noltii extract elevated eNOS levels in a dosedependent manner.

On the other hand, our results indicated that increased contractile responses to phenylephrine and 5-HT were normalized by Z. noltii extract treatment with an accompanying reduction in sensitivity. Impaired NO synthesis is known to increase vasocontractility in diabetic animals (Benter et al., 2005). However, in our study, inhibition of NO synthesis by L-NAME did not result in further increments in phenylephrine and 5-HT contractions. Thus, we have questioned the role of ROS produc 
-tion in the contractile responses. Indeed, as reflected by lucigenin and luminol chemiluminescence, $\mathrm{Z}$. noltii extract, inhibited the production of $\mathrm{O}_{2}{ }^{-}$and other reactive species. Since ROS, especially $\mathrm{O}_{2}{ }^{\cdot-}$ are regarded as endothelium-derived contracting factors which play major roles in the regulation of arterial tone (Katusic and Vanhoutte, 1989), free radical scavenging activity of the extract may therefore account for the attenuated contractile responses observed in Z. noltii extract-treated alloxan-diabetic animals.

\section{Conclusion}

Z. noltii extract is shown to lower blood glucose and prevent hyperglycemia-induced endothelial dysfunction. Anti-oxidant/free radical scavenging properties of the extract are unlikely to be the only mechanisms underlying its anti-diabetic action.

\section{Ethical Issue}

The experiments were carried out in accordance with the guidelines of Local Ethics Committee of Animal Experiments, Ege University, Izmir, Turkey (B.30.2.EGE.0.01.00.01/04-44215a).

\section{Acknowledgments}

This work was carried out in laboratories of Department of Pharmaceutical Botany and Department of Pharmacology (Ege University, Faculty of Pharmacy). Authors thank Prof. Ulvi Zeybek and Prof. Levent Ustunes for their kind supports. This study was supported by Ege University Project Fund 06/ $\mathrm{ECZ} / 003$.

\section{References}

Achamlale S, Rezzonico B, Grignon-Dubois M. Rosmarinic acid from beach waste: Isolation and HPLC quantification in Zostera detritus from Arcachon Lagoon. Food Chem. 2009; 113: 878-83.

Benter IF, Yousif MH, Canatan H, Akhtar S. Inhibition of $\mathrm{Ca}^{2+}$ / calmodulin-dependent protein kinase II, RAS-GTPase and 20-hydroxyeicosatetraenoic acid attenuates the development of diabetes-induced vascular dysfunction in the rat carotid artery. Pharmacol Res. 2005; 52: 252-57.

Bergmeyer HW, Bernt E. Practical clinical biochemistry, In: Varley H, Gowenlock AH, Bell M. eds. London, England, William Heinemann Medicinal Books Ltd., 1980, p 741.

Brod J, Sirota JH. Practical clinical biochemistry, In: Varley H, Gowenlock AH, Bell M. (eds). London, England, William Heinemann Medicinal Books Ltd., 1948, p 190.

Chowienczyk PJ, Brett SE, Gopaul NK, Meeking D, Marchetti M, Russell-Jones DL, Anggard EE, Ritter JM. Oral treatment with an anti-oxidant (raxofelast) reduces oxidative stress and improves endothelial function in men with type II diabetes. Diabetologia 2000; 43: 974-77.

Cooperstein SJ, Walkins D. Action of toxic drugs on islet cells. In: The Islets of Langerhans. New York, USA, Academic Press, 1981, pp 387-90.

Cuny P, Serve L, Jupin H, Boudouresque CF. Water soluble phenolic compounds of the marine phanerogam Posidonia oceanica in a Mediterranean area colonised by the introduced chlorophyte Caulerpa taxifolia. Aquat Bot. 1995; 52: 237-42.

Fava D, Cassone-Faldetta M, Laurenti O, De Luca O, Ghiselli A, De Mattia G. Gliclazide improves anti-oxidant status and nitric oxide-mediated vasodilation in type 2 diabetes. Diabet Med. 2002; 19: 752-57.

Ferreira HC, Serra CP, Lemos VS, Braga FC, Cortes SF. Nitric oxide-dependent vasodilatation by ethanolic extract of Hancornia speciosa via phosphatidyl-inositol 3-kinase. J Ethnopharmacol. 2007; 109: 161-64.

Epstein FH. Glucose transporters and insulin action: Implication for insulin resistance and diabetes mellitus. New Eng J Med. 1999; 341: 248-57.

Giugliano D, Ceriello A, Paolisso G. Oxidative stress and diabetic vascular complications. Diabetes Care. 1996; 19: 257 $-67$.

Gokce G, Haznedaroglu MZ. Evaluation of antidiabetic, antioxidant and vasoprotective effects of Posidonia oceanica extract. J Ethnopharmacol. 2008; 115: 122-30.

Gong FY, Li FL, Zhang WM, Li JZhang Z. Effects of crude flavonoids from tatary buckwheat on alloxan-induced oxidative stress in mice. Bangladesh J Pharmacol. 2012; 7: 124-30.

Grignon-Dubois M, Rezzonico B, Alcoverro T. Regional scale patterns in seagrass defences: Phenolic acid content in Zostera noltii. Estuar Coast Shelf S. 2012; 114: 18-22.

Guevara I, Iwanejko J, Dembinska-Kiec A, Pankiewicz J, Wanat A, Anna P, Golabek I, Bartus S, Malczewska-Malec M, Szczudlik A. Determination of nitrite/nitrate in human biological material by the simple griess reaction. Clin Chim Acta. 1998; 274: 177-88.

Guo Z, Su W, Allen S, Pang H, Daugherty A, Smart E, Gong MC. Cox-2 up-regulation and vascular smooth muscle contractile hyperreactivity in spontaneous diabetic $\mathrm{db} / \mathrm{db}$ mice. Cardiovasc Res. 2005; 67: 723-35.

Haklar G, Saybasili H, Yuksel M, Yalcin AS. Measurement of nitric oxide in hippocampal slices: Induction with nitroso compounds and the effect of depolarization. Acta Neurobiol Exp (Wars). 2003; 63: 319-25.

Haslam RH. Practical clinical biochemistry, In: Varley $\mathrm{H}$, Gowenlock AH, Bell M. eds. London, England, William Heinemann Medicinal Books Ltd., 1966, p 459.

Karasu C. Time course of changes in endothelium-dependent and -independent relaxation of chronically diabetic aorta: Role of reactive oxygen species. Eur J Pharmacol. 2000; 392: 163-73.

Katusic ZS, Vanhoutte PM. Superoxide anion is an endothelium-derived contracting factor. Am J Physiol. 1989; 25: H33-H37. 
King EJ, Armstrong AR. Practical clinical biochemistry, In: Varley H, Gowenlock AH, Bell M. eds. London, England, William Heinemann Medicinal Books Ltd., 1980, p 897.

Laight DW, Carrier MJ, Anggard EE. Endothelial cell dysfunction and the pathogenesis of diabetic macroangiopathy. Diabetes Metab Res Rev. 1999; 15: 274-82.

Lamaison JL, Petitjean-Freytet C, Carnat A. Rosmarinic acid, total hydroxycinnamic derivatives and anti-oxidant activity of Apiaceae, Boraginaceae and Lamiceae medicinals. Ann Pharm Fr. 1990; 48: 103-08.

Lowry $\mathrm{OH}$, Rosebrough NJ, Farr AL, Randall RJ. Protein measurement with the folin phenol reagent. J Biol Chem. 1951; 193: 265-75.

Meraji S, Jayakody L, Senaratne MP, Thomson AB, Kappagoda T. Endothelium-dependent relaxation in aorta of BB rat. Diabetes 1987; 36: 978-81.

Metz SA. Is phospholipase A2 a "Glucose sensor" responsible for the phasic pattern of insulin release? Prostaglandins 1984; 27 : 147-58.

Mireia V, Angel B, Guillem C, Ibon G, Joxe Mikel G. Modelling suitable estuarine habitats for Zostera noltii, using ecological niche factor analysis and bathymetric lidar. Estuar Coast Shelf S. 2011; 94: 144-54.

Mohan DS, Saraswathy M, Kurup MKG. Attenuation of hyperglycemia and hyperlipidemia in high calorie fed/ streptozotocin-treated rats by hydromethanolic extract of padina tetrastromatica. Bangladesh J Pharmacol. 2014; 9: 3742.

Murugan P, Pari L. Anti-oxidant effect of tetrahydrocurcumin in streptozotocin-nicotinamide induced diabetic rats. Life Sci. 2006; 79: 1720-28.

Ndiaye M, Chataigneau M, Lobysheva I, Chataigneau T, Schini -Kerth VB. Red wine polyphenol-induced, endothe-liumdependent no-mediated relaxation is due to the redoxsensitive PI3-kinase/AKT-dependent phosphorylation of endothelial NO-synthase in the isolated porcine coronary artery. FASEB J. 2005; 19: 455-57.

Newberry RW, Ortega MJ, Zubia E, Romagni-Colvin JG. Seasonal variation in the phenolic secondary metabolites of Zostera noltii from the bay of Cadiz. 241 st ACS National Meeting and Exposition, Anaheim, United States, 2011.

Oyama Y, Kawasaki H, Hattori Y, Kanno M. Attenuation of endothelium-dependent relaxation in aorta from diabetic rats. Eur J Pharmacol. 1986; 132: 75-78.

Papenbrock J. Highlights in Seagrasses' Phylogeny, P, and Metabolism: What makes them special? ISRN Botany 2012; Article ID 103892 http://www.hindawi.com/journals/ isrn.botany/2012/103892/.

Perfumi M, Tacconi R. Antihyperglycemic effect of fresh Opuntia dillenii fruit from Tenerife (Canary Islands). Pharm
Biol. 1996; 34: 41-47.

Rao BK, Rao CH. Hypoglycemic and antihyperglycemic activity of Syzygium alternifolium (wt.) walp. seed extracts in normal and diabetic rats. Phytomedicine 2001; 8: 88-93.

Rehman A, Nourooz-Zadeh J, Moller W, Tritschler H, Pereira P, Halliwell B. Increased oxidative damage to all DNA bases in patients with type ii diabetes mellitus. FEBS Lett. 1999; 448: $120-22$.

Rende F, Canese S, Rossi L, Izzi A, Nonnis O, Maggi C. Monitoring of seagrasses through underwater photographic images and video: Underwater pipelines case study. Mediterranean Seagrass Workshop, Essaouira, Morocco, 2012.

Sabu MC, Smitha K, Kuttan R. Anti-diabetic activity of green tea polyphenols and their role in reducing oxidative stress in experimental diabetes. J Ethnopharmacol. 2002; 83: 10916.

Sakurai K, Katoh M, Someno K, Fujimoto Y. Apoptosis and mitochondrial damage in ins-1 cells treated with alloxan. Biol Pharm Bull. 2001; 24: 876-82.

Sato Y, Itagaki S, Kurokawa T, Ogura J, Kobayashi M, Hirano $\mathrm{T}$, Sugawara $\mathrm{M}$, Iseki K. In vitro and in vivo anti-oxidant properties of chlorogenic acid and caffeic acid. Int J Pharm. 2011; 403: 136-38.

Shukla N, Thompson CS, Angelini GD, Mikhailidis DP, Jeremy JY. Low micromolar concentrations of copper augment the impairment of endothelium-dependent relaxation of aortae from diabetic rabbits. Metabolism 2004; 53: 1315-21.

Signorini AM, Fondelli C, Renzoni E, Puccetti C, Gragnoli G, Giorgi G. Anti-oxidant effect of gliclazide, glibenclamide and metformin in patients with type 2 diabetes mellitus. Curr Ther Res Clin E. 2002; 63: 411-20.

Trinder P. Practical clinical biochemistry, In: Varley $\mathrm{H}$, Gowenlock AH, Bell M. eds. London, England, William Heinemann Medicinal Books Ltd., 1976, p 389.

Walsh MF, Pek SB. Possible role of endogenous arachidonic acid metabolites in stimulated release of insulin and glucagon from the isolated, perfused rat pancreas. Diabetes 1984; 33: 929-36.

Wang HD, Xu S, Johns DG, Du Y, Quinn MT, Cayatte AJ, Cohen RA. Role of NADPH oxidase in the vascular hypertrophic and oxidative stress response to angiotensin II in mice. Circ Res. 2001; 88: 947-53.

Zeljan M, Misko P. Investigation of chemical composition of Zostera noltii Hornem. Farm Glas. 2000; 56: 109-18.

Zitouni K, Nourooz-Zadeh J, Harry D, Kerry SM, Betteridge DJ, Cappuccio FP, Earle KA. Race-specific differences in anti -oxidant enzyme activity in patients with type 2 diabetes: A potential association with the risk of developing nephropathy. Diabetes Care. 2005; 28: 1698-703.
Author Info
e-mail: zeki.haznedaroglu@gmail.com 